\title{
Mechanistic insight to selective deoxygenation of L-lysine to produce biobased amines
}

Shaoqu Xie ${ }^{\mathrm{a}}$, Chuhua Jia ${ }^{\mathrm{a}}$, Ziling Wang ${ }^{\mathrm{c}}$, Scott Sergio Go Ong ${ }^{\mathrm{a}}$, Mei-jun Zhu ${ }^{\mathrm{c}}$,Hongfei

$\operatorname{Lin}^{\mathrm{a}, \mathrm{b}, *}$

aThe Gene and Linda Voiland School of Chemical Engineering and Bioengineering, Washington State University, 1505 Stadium Way, Pullman, WA 99164, USA

b The Department of Biological Systems Engineering, Washington State University, 1935

E. Grimes Way, Pullman, WA 99164, USA

c The School of Food Science, Washington State University, 100 Dairy Road, Pullman, WA 99164, USA

* Corresponding author: hongfei.lin@wsu.edu (H. Lin).

Number of pages: 22

Number of figures: 12

Number of tables: 2

Number of schemes: 1 


\section{Determination and quantification of the products}

\section{Determinations of the gaseous products and liquid phase products}

To identify the gaseous products, the reactor was connected to a gas chromatograph (GC) Shimadzu GC-2014, equipped with a thermal conductivity detector (TCD) and a $2 \mathrm{~m}$ (L) $\times 0.32 \mathrm{~mm}$ (ID) $10 \%$ Carbowax $20 \mathrm{~m}$ Ch packed column on the left and a 12.5 $\mathrm{m}(\mathrm{L}) \times 0.32 \mathrm{~mm}$ (ID) packed column which is a combination of $3 \mathrm{~m}$ Hayesep $\mathrm{D}, 4 \mathrm{~m} \mathrm{HS}$, and $2.5 \mathrm{~m} \mathrm{HN}$ on the right. The oven temperature was held at $80{ }^{\circ} \mathrm{C}$ for $10 \mathrm{~min}$ and then soared to $150{ }^{\circ} \mathrm{C}$ at a rate of $5{ }^{\circ} \mathrm{C} / \mathrm{min}$. The injector and detector temperatures were fixed at $150^{\circ} \mathrm{C}$. The carrier gas for the analysis was ultra-high purity helium which was run at $40 \mathrm{~mL} / \mathrm{min}$ for the left column and $20 \mathrm{~mL} / \mathrm{min}$ for the right column. Ultra-purity $\mathrm{N}_{2}, \mathrm{CO}_{2}$, $\mathrm{CH}_{4}$, and $\mathrm{H}_{2}$ and the mixed gases containing $\mathrm{CO}$ and $\mathrm{O}_{2}$ were used to characterize and identify the gaseous products according to the $\mathrm{GC}$ retention time.

After the reactor was disassembled, the liquid phase was filtered to remove the solids and neutralized by using $\mathrm{NaOH}$ if an acid was used. The liquid phase was diluted to $50 \mathrm{~mL}$ with water for quantitating the conversion of feedstock and the yields of the products. $5 \mathrm{~mL}$ of the liquid sample was withdrawn to a vial and mixed well with $4.5 \mathrm{~g}$ of potassium carbonate and $1 \mathrm{~mL}$ of acetonitrile. Afterward, the products from the 
conversion of L-lysine were salted out with the aid of acetonitrile to form an organic phase. The liquid products in the organic phase were identified by GCMS QP-2020 (Shimadzu) equipped with a Shimadzu SH-Rxi-5SIL MS column (30 m x $0.25 \mathrm{~mm}$ ID, 0.25 um film thickness), a flame ionization detector (FID) and a high-performance ion source. Ultra-high purity helium was used as the carrier gas. The oven temperature was first held at $50^{\circ} \mathrm{C}$ for $2 \mathrm{~min}$, soared to $300^{\circ} \mathrm{C}$ at a rate of $20^{\circ} \mathrm{C} / \mathrm{min}$, and then kept at $300^{\circ} \mathrm{C}$ for $10 \mathrm{~min}$. The injector and detector temperatures were fixed at $300^{\circ} \mathrm{C}$. The ion source and interface temperatures were $200^{\circ} \mathrm{C}$ and $250^{\circ} \mathrm{C}$, respectively. $1.0 \mu \mathrm{L}$ of the organic phase was injected into the system with a split ratio of 10: 1. The data were obtained from $50 \mathrm{~m} / \mathrm{z}$ to $350 \mathrm{~m} / \mathrm{z}$ and further used to characterize and identify the products by comparing those mass spectra from the National Institute of Standards and Technology's (NIST) mass spectral data library. After the spectra resolution, all the products were further determined by using pure standards, which was based on the GC retention time.

\section{Quantification of the conversion and the products}

The liquid products were quantified by a GC Shimadzu GC-2010 equipped with a Shimadzu SHRXI-5MS column ( $30 \mathrm{~m} \times 0.25 \mathrm{~mm}$ ID, $0.25 \mathrm{um}$ DF) and a flame ionization detector (FID). Ultra-high purity $\mathrm{N}_{2}$ was used as the carrier gas. The oven temperature was first held at $50^{\circ} \mathrm{C}$ for $2 \mathrm{~min}$, increased to $300^{\circ} \mathrm{C}$ at a rate of $20^{\circ} \mathrm{C} / \mathrm{min}$, and then kept at $300^{\circ} \mathrm{C}$ for $10 \mathrm{~min}$. The injector and detector temperatures were fixed at 
$300^{\circ} \mathrm{C} .1 .0 \mu \mathrm{L}$ of the liquid sample was injected into the system with a split ratio of 19.9:1. The analysis of the liquid-phase product samples was conducted by the external standard method. $\mathrm{N}^{\varepsilon}$-Z-L-lysinol was first deprotected by catalytic hydrogenation to remove the carboxybenzyl group in methanol before use ${ }^{1}$.

L-lysine and ammonium hydroxide derivatives were obtained by the reaction in which $300 \mathrm{uL}$ of borate buffer $(\mathrm{pH}=9,9.5343 \mathrm{~g}$ sodium borate 10 hydrate and $1.5458 \mathrm{~g}$ boric acid were diluted with water to $1 \mathrm{~L}$ ), $100 \mathrm{uL}$ of pure methanol, $47 \mathrm{uL}$ of deionized water, $3 \mathrm{uL}$ of DEEMM, and $30 \mathrm{uL}$ of the liquid sample were added into the vial ${ }^{2}$. The vials were sealed and heated at $70^{\circ} \mathrm{C}$ for $2 \mathrm{~h}$ to allow complete degradation of excess $\operatorname{DEEMM}^{3}$ and derivatization.

The L-lysine and ammonium hydroxide contents of the derived sample were analyzed by high-performance liquid chromatography (HPLC) LC-2030 equipped with a C18 column, a UV-Vis Detector and a Refractive Index Detector (RID) at $35^{\circ} \mathrm{C}$. Mobile phase A was HPLC grade acetonitrile and mobile phase B was sodium acetate buffer (4.84 $\mathrm{g}$ of sodium acetate and $2.46 \mathrm{~g}$ acetic acid was diluted with water to $4 \mathrm{~L}$ ). The flow rate was kept at $1 \mathrm{~mL} / \mathrm{min}$ and the gradient elution was used: $0 \sim 2 \mathrm{~min}, 20 \%$ acetonitrile $/ 80 \%$ sodium acetate buffer; $2 \sim 32 \mathrm{~min}, 25 \%$ acetonitrile $/ 75 \%$ sodium acetate buffer; $32 \sim 40 \mathrm{~min}, 60 \%$ acetonitrile $/ 40 \%$ sodium acetate buffer; $40 \sim 45 \min : 20 \%$ acetonitrile $/ 80 \%$ sodium acetate buffer. The UV light wavelength was set to $284 \mathrm{~nm}$ during the analysis. 
After the determinations of the L-lysine and products contents, the conversion of L-lysine and the product yields are calculated using the following equations:

$$
\begin{aligned}
& \text { Conversion } \%=1-\frac{\text { mole of lysine after reaction }}{\text { mole of lysine before reaction }} \times 100 \% \\
& \text { Product Yield } \%=\frac{\text { mole of a product after reaction }}{\text { mole of lysine before reaction }} X 100 \%
\end{aligned}
$$

\section{In-situ ATR-FTIR analysis}

The ATR-FTIR analysis was performed on the Bruker Tensor II spectrometer with a Harrick Horizon ${ }^{\mathrm{TM}}$ and a Harrick temperature controller ATC-024-4. A $2.89 \mathrm{~mL}$ liquid sampling cell with a Ge horizon trough (HON-LSP-J) was used to carry out the catalytic reactions.

\section{Film Preparation}

The liquid suspension of $\mathrm{Ru} / \mathrm{AC}$ was prepared by mixing $0.03 \mathrm{~g} \mathrm{Ru} / \mathrm{AC}$ and $5 \mathrm{~mL}$ deionized water in a vial. Then $1 \mathrm{~mL}$ of the catalyst suspension was withdrawn by a pipette to coat on the Ge horizon trough. The cell was dried for $1 \mathrm{~h}$ at $90{ }^{\circ} \mathrm{C}$. Afterwards, $5 \mathrm{~mL} / \mathrm{min}$ of $\mathrm{H}_{2}$ was introduced into the cell together with the $\mathrm{N}_{2}$ flow at a constant rate of $25 \mathrm{~mL} / \mathrm{min}$ to reduce the catalyst after the temperature was increased to $150{ }^{\circ} \mathrm{C}$. After 1 hour, the atmosphere was switched to $25 \mathrm{~mL} / \mathrm{min}$ of $\mathrm{N}_{2}$ again while the temperature controller stopped heating to cool down the thin film.

\section{In-situ ATR-FTIR analysis}


For in-situ observation of the conversion of L-lysine, L-lysine (0.5 mmol) was dissolved in $5 \mathrm{~mL}$ of $\mathrm{D}_{2} \mathrm{O}$ and acidized with $200 \mu \mathrm{L}$ of $\mathrm{H}_{3} \mathrm{PO}_{4}$. Then $600 \mu \mathrm{L}$ of the L-lysine deuterated solution was dropped onto the catalyst film by a $1000 \mu \mathrm{L}$ Eppendorf pipette. The cell was sealed, purged with $5 \mathrm{~mL} / \mathrm{min}$ of $\mathrm{H}_{2}$, and pressurized with 9 bar of $\mathrm{H}_{2}$. The temperature was raised to $150{ }^{\circ} \mathrm{C}$ and then the spectra started to be acquired. For comparison, 2-piperidinemethanol $(0.46 \mathrm{mmol})$ was employed for the in-situ observation of the conversion of the alcoholic intermediate under the same conditions as those of the conversion of L-lysine except the reaction temperature $\left(175^{\circ} \mathrm{C}\right)$.

To investigate the effect of the acid co-catalysts, $0.1 \mathrm{~mol} / \mathrm{L}$ L-lysine $\mathrm{D}_{2} \mathrm{O}$ solution was prepared with varying the acid concentration $\left(\mathrm{H}_{2} \mathrm{SO}_{4}\right.$ or $\left.\mathrm{H}_{3} \mathrm{PO}_{4}\right)$. The weak acid, $\mathrm{H}_{3} \mathrm{BO}_{3}$, was dissolved in the $0.1 \mathrm{~mol} / \mathrm{L}$ L-lysine solution directly. To investigate the effect of L-lysine concentration, $\mathrm{D}_{2} \mathrm{O}$ was directly added to dilute the $0.1 \mathrm{~mol} / \mathrm{L}$ L-lysine $\mathrm{D}_{2} \mathrm{O}$ solution in the presence of $\mathrm{H}_{3} \mathrm{PO}_{4}$ (the molar ratio of $\mathrm{H}_{3} \mathrm{PO}_{4}$ to lysine was kept to 5.93). The in-situ ATR-FTIR experiments were performed at room temperature after dropping the liquid samples to cover the Ge horizon trough. The spectra were collected from 400 to $4000 \mathrm{~cm}^{-1}$ and the measurement for each sample was repeated for a minimum of 2 times. 


\section{Catalyst screening}

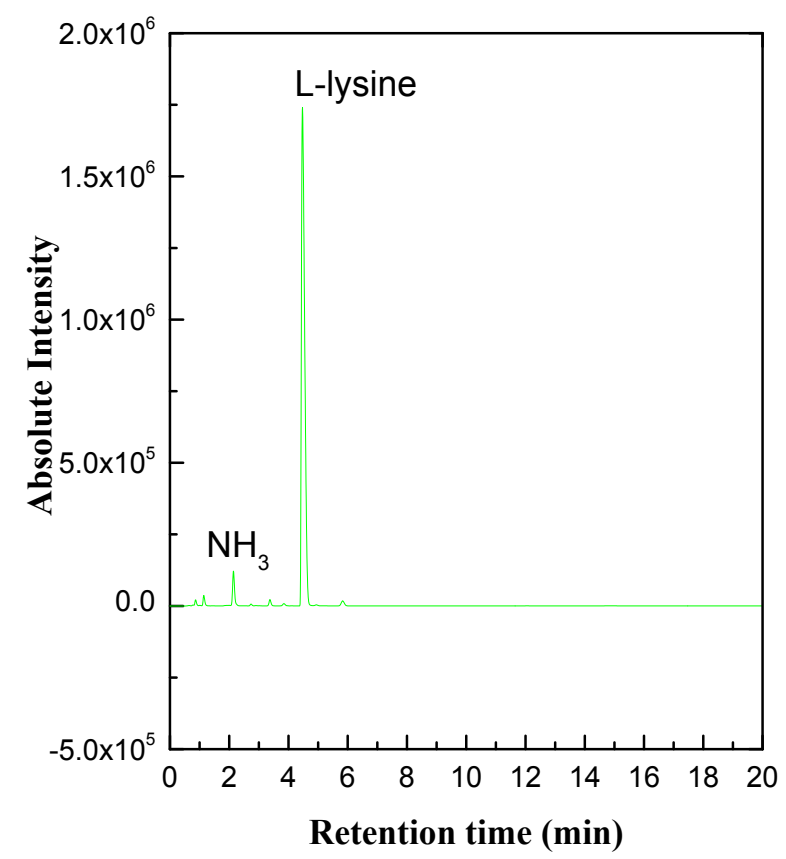

Figure S1 HPLC spectrum (UV-Vis detector) of the products from the $\mathrm{Ru} / \mathrm{C}$-based catalytic reaction under alkaline condition. Reaction condition: L-lysine $(0.7 \mathrm{mmol})$, catalyst $(0.05 \mathrm{~g})$, water $(10 \mathrm{~mL}), 150^{\circ} \mathrm{C}, 2 \mathrm{~h}, 28.2$ bar H$_{2}, 700 \mathrm{rpm}, 0.12 \mathrm{~g} \mathrm{KOH}$.

Table S1 Yields of ammonium/ammonia. Reaction condition: 1) without acid or base: L-lysine ( $0.5 \mathrm{mmol}), \mathrm{Ru} / \mathrm{C}$ catalyst $(0.03 \mathrm{~g})$, water $(5 \mathrm{~mL}), 150 \mathrm{oC}, 2 \mathrm{~h}, 28.2$ bar H2, $700 \mathrm{rpm}$; 2) under alkaline condition: L-lysine $(0.7 \mathrm{mmol}), \mathrm{Ru} / \mathrm{C}$ catalyst (0.05 g), water (10 mL), 150 oC, 2 h, 28.2 bar H2, $700 \mathrm{rpm}, 0.12 \mathrm{~g} \mathrm{KOH}$. 


\begin{tabular}{lc}
\hline Reaction system & The yield of ammonium/ammonia (\%) \\
\hline $\mathrm{Ru} / \mathrm{C}+\mathrm{KOH}$ & $>33.17$ \\
$\mathrm{Ru} / \mathrm{C}$ & $>12.17$ \\
$\mathrm{Rh} / \mathrm{C}+\mathrm{KOH}$ & $>9.38$ \\
\hline
\end{tabular}

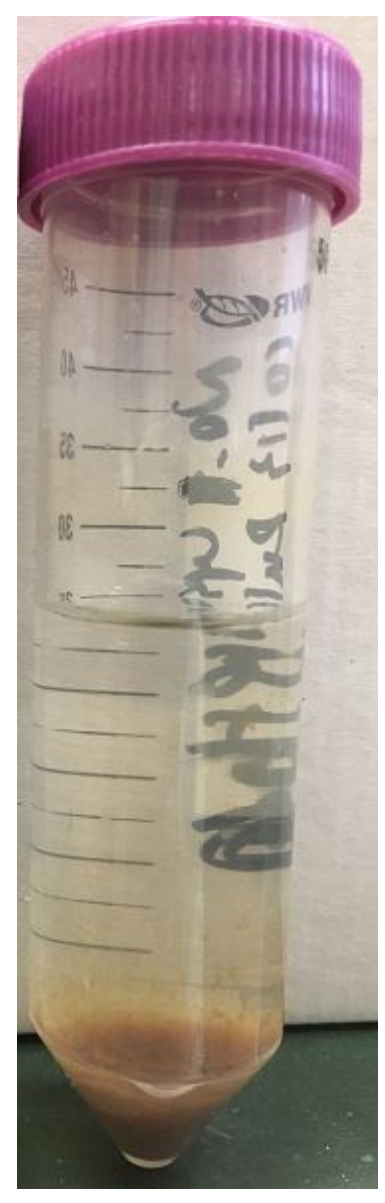

Figure S2 Formation of solid with the aid of $\mathrm{H}_{2} \mathrm{SO}_{4}$. Reaction condition: L-lysine $(0.5$ mmol), $\mathrm{Ru} / \mathrm{C}(0.03 \mathrm{~g})$, water $(5 \mathrm{~mL}), 150{ }^{\circ} \mathrm{C}, 2 \mathrm{~h}, 28.2$ bar $\mathrm{H}_{2}, 700 \mathrm{rpm}, 300 \mu \mathrm{L}$ of $\mathrm{H}_{2} \mathrm{SO}_{4}$. 


\section{Role of hydrogen}

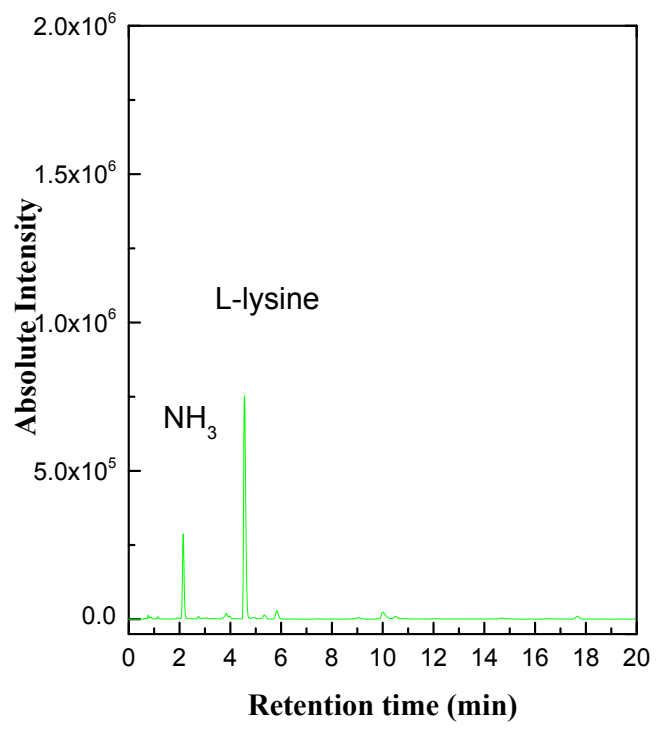


Figure S3 HPLC spectrum (UV-Vis detector) of the products from the $\mathrm{Ru} / \mathrm{C}$-based catalytic reaction under 0 psi of $\mathrm{H}_{2}$. Reaction condition: L-Lysine $(0.5 \mathrm{mmol}), 5 \% \mathrm{Ru} / \mathrm{C}$ $(0.03 \mathrm{~g})$, water $(5 \mathrm{~mL}), \mathrm{H}_{3} \mathrm{PO}_{4}(4.45 \mathrm{mmol}), 2 \mathrm{~h}, 150{ }^{\circ} \mathrm{C}$.

The lysinol yield dominated, suggesting that the amino group has little effect on the reactivity of the hydroxy in lysinol. Moreover, the formation of a significant amount of diamines and piperidinemethanols, while a negligible amount of carboxylic acids, implied the suppression of the deamination side reactions. The 1,5-diaminohexane yield shows an increase with increasing the $\mathrm{H}_{2}$ pressure, showing the synchronous trend with lysinol. This result indicated that the formation of 1,5-diaminohexane was specific through the further reduction of lysinol. ${ }^{4}$ Further increasing the $\mathrm{H}_{2}$ pressure had no significant effect on the yields of cadaverine and piperidinemethanols, indicating that it is hard to cleave the $\mathrm{C}-\mathrm{C}$ bond at relatively lower temperatures.

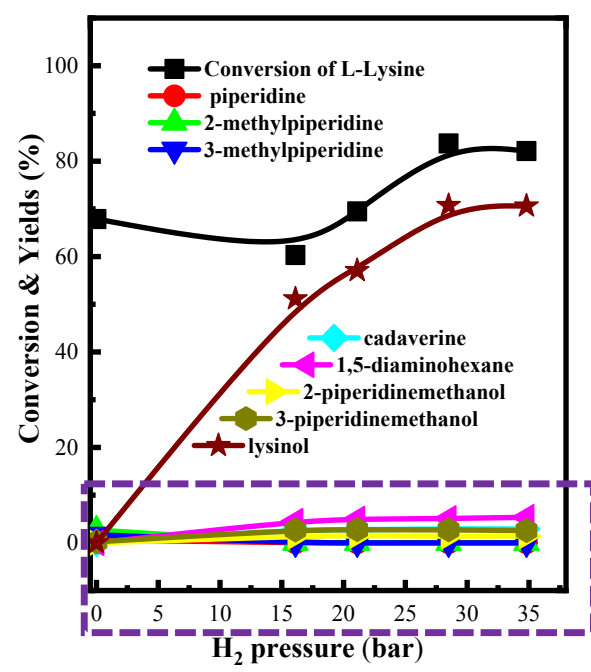

(a)

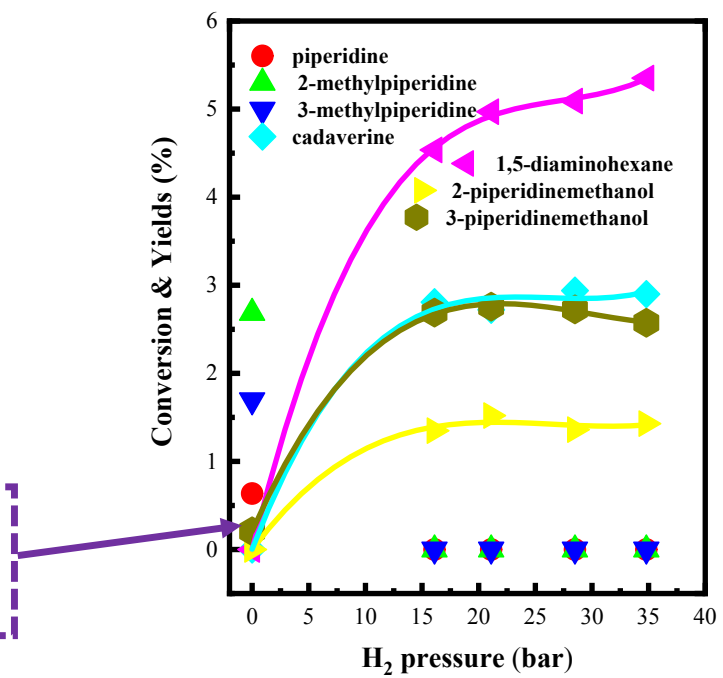

(b)

Figure S4 Effect of $\mathrm{H}_{2}$ pressure on the conversion of L-Lysine to N-containing chemicals (a), magnification of lower region in Figure 2a (b). Reaction condition: L-Lysine (0.5 mmol), $5 \% \mathrm{Ru} / \mathrm{C}(0.03 \mathrm{~g})$, water (5 mL), $\mathrm{H}_{3} \mathrm{PO}_{4}$ (4.45 mmol), $2 \mathrm{~h}, 150{ }^{\circ} \mathrm{C}$. 


\section{$\mathrm{C}-\mathrm{C}$ and $\mathrm{C}-\mathrm{N}$ bonds cleavage and product distribution}

The increase in the $\mathrm{H}_{2}$ pressure could not promote the further deoxygenation of lysinol whereas increasing the temperature was efficient for enhancing the $\mathrm{C}-\mathrm{C}$ bond cleavage, and simultaneously aggravating the deamination. As such, the cascade of coupling reactions responsible for these subsequent deoxygenation and deamination steps reduced the yield of lysinol, yielding cadaverine and 2-piperidinemethanol. However, another end product, piperidine, increased with the progress of the cleavage of the $\mathrm{C}-\mathrm{C}$ bond in 2-piperidinemethanol and the cleavage of the $\mathrm{C}-\mathrm{N}$ bond in cadaverine, respectively. The formation of 2-methylpiperinedine was also the result of the $\mathrm{C}-\mathrm{C}$ bond and $\mathrm{C}-\mathrm{N}$ bond cleavages, together with the hydrogenation of the alcoholic hydroxyl group.

\section{Protection of the amino group}




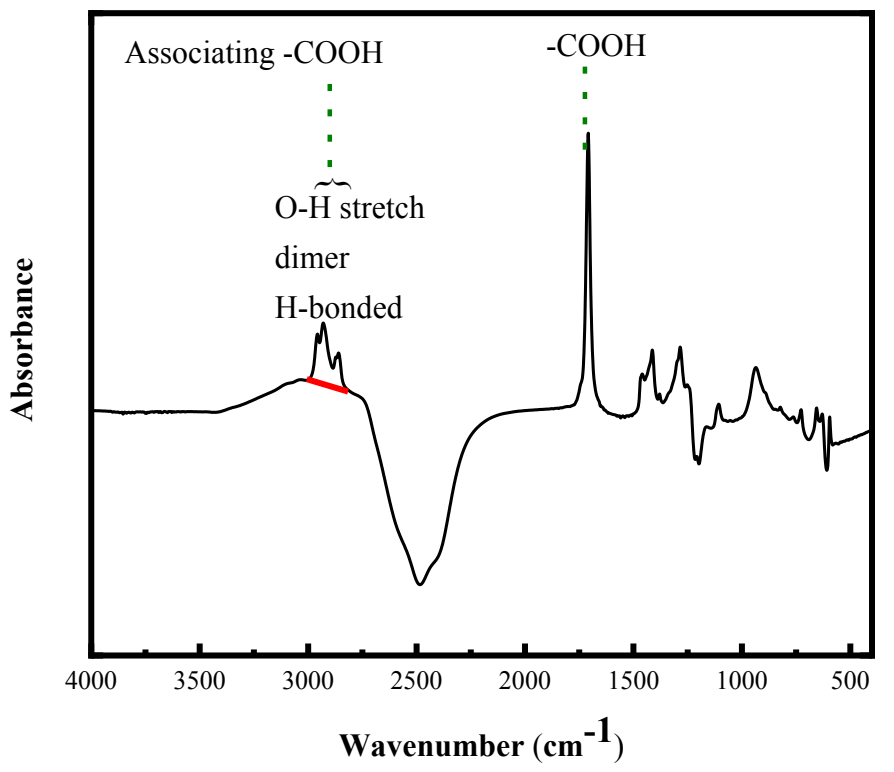

Figure S5 ATR-FTIR spectra of pure heptanoic acid using $\mathrm{D}_{2} \mathrm{O}$ as background at room temperature. The hydrogen bonds of carboxylic acid dimers were identified in this Figure. For more details about the dimeric pair of carboxylic acid, please visit this website: https://chem.pg.edu.pl/documents/175230/54717567/8.\%20IR.pdf.

As a strong acid, $\mathrm{H}_{2} \mathrm{SO}_{4}$ has a stronger ability or tendency to donate a proton than $\mathrm{H}_{3} \mathrm{PO}_{4}$, implying that the carboxylate ions could be easier to be fully protonated to form the carboxyl groups. The $\mathrm{pH}$ value of the solvent at a molar ratio of $\mathrm{H}_{2} \mathrm{SO}_{4}$ to L-lysine, 1.13:1, is equal to that at a molar ratio of $\mathrm{H}_{3} \mathrm{PO}_{4}$ to L-lysine, 4.45:1, as shown in Figure S6. In these cases, the amino group was fully protonated by $\mathrm{H}_{3} \mathrm{PO}_{4}$ as the peak at 1614 $\mathrm{cm}^{-1}$ disappeared, whereas only a small amount of amino group was protonated by $\mathrm{H}_{2} \mathrm{SO}_{4}$, as can be seen in Figure S7. The equilibrium between the amine and the ammonium demonstrated that the molar ratio of $\mathrm{H}_{2} \mathrm{SO}_{4}$ to L-lysine at 1.13:1 cannot introduce an electrical charge on the amino groups completely. Over the catalytic reaction over $\mathrm{Ru} / \mathrm{C}$, only $84.5 \%$ of the $\mathrm{N}$-containing chemicals formed via 
deoxygenation of the carboxyl groups along with the deamination, resulting in $42.8 \%$ of piperidine when 1.13 times of $\mathrm{H}_{2} \mathrm{SO}_{4}$ was used, as shown in Table S2 (Entry 2).

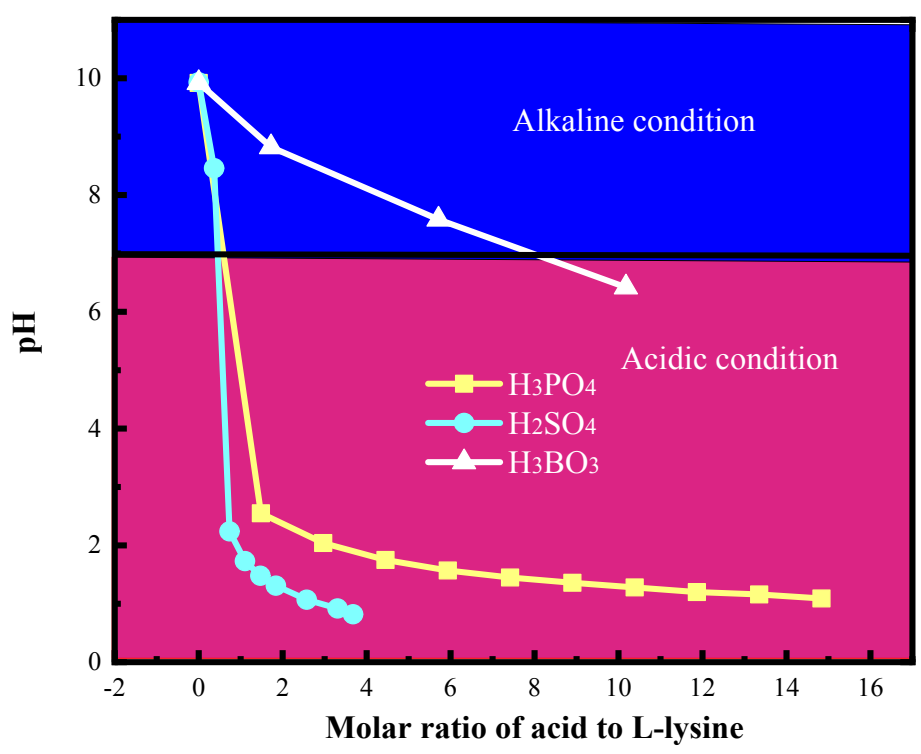

Figure S6 Solvent environment with different acid loadings. L-Lysine ( $0.5 \mathrm{mmol})$, water $(5 \mathrm{~mL})$.

Moreover, the severe side reaction was the condensation to form solid yellow byproducts. It appears that increasing the dosage of $\mathrm{H}_{2} \mathrm{SO}_{4}$ can fully protonate the functional groups at a ratio of $3.75: 1$, as demonstrated by the associating carboxyl groups in Figure S7. However, the sharp decrease in $\mathrm{pH}$ in Figure S6 may result in the unexpected condensation by the dehydration between the functional groups. Moreover, the reduction of $\mathrm{H}_{2} \mathrm{SO}_{4}$ produced the odoriferous sulfur compound that was poisonous to $\mathrm{Ru} / \mathrm{C}$. As a result, the catalytic activity of $\mathrm{Ru} / \mathrm{C}$ declined sharply, leading to the stagnant deoxygenation process (Entry 3 in Table S2) ${ }^{5}$ Figure S8 shows the effect of the molar ratio of $\mathrm{H}_{3} \mathrm{BO}_{3}$ to L-lysine on the FTIR spectra of L-lysine in $\mathrm{D}_{2} \mathrm{O}$ at room temperature. 
Because $\mathrm{H}_{3} \mathrm{BO}_{3}$ is much less capable of donating protons, no carboxyl groups were formed at a high molar ratio of $\mathrm{H}_{3} \mathrm{BO}_{3}$ to L-lysine (6.89:1), indicating that the deoxygenation of L-lysine to the $\mathrm{N}$-containing chemicals over $\mathrm{Ru} / \mathrm{C}$ is not effective with $\mathrm{H}_{3} \mathrm{BO}_{3}$. This prediction is consistent with experimental results that show only $16.5 \%$ of piperidine and a trace amount of methylpiperidine, indicating that boric acid (weak acid) cannot protect the amino group efficiently (Entry 1 in Table S2). These findings, together with the role of hydrogen, suggest that the protonation of the amino group is the necessary step that accurately describes the role of acid on protecting the remaining two amino groups, which is a key step for the selective deoxygenation of lysinol.

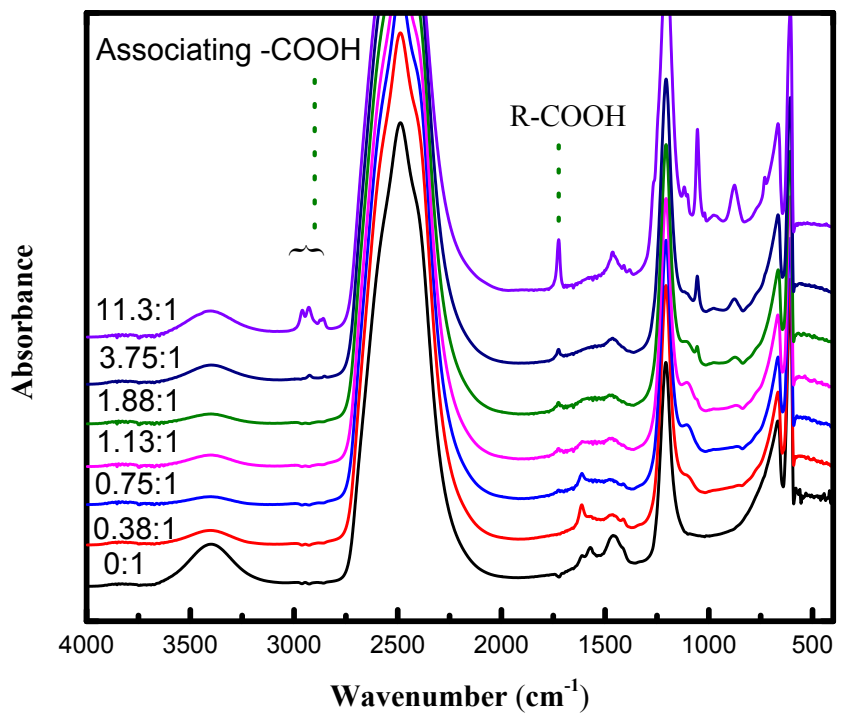

Figure S7. Effect of $\mathrm{H}_{2} \mathrm{SO}_{4}$ to L-lysine molar ratio on the FTIR spectra of L-lysine in $\mathrm{D}_{2} \mathrm{O}$ at room temperature.

Table S2 Conversion of L-lysine using $\mathrm{H}_{2} \mathrm{SO}_{4}$ and $\mathrm{H}_{3} \mathrm{BO}_{3}$. Reaction condition: Lysine 
(0.5 mmol), $5 \% \mathrm{Ru} / \mathrm{C}(0.03 \mathrm{~g})$, water $(5 \mathrm{~mL}), 1 \mathrm{~h}, 200{ }^{\circ} \mathrm{C}, 28.2$ bar $\mathrm{H}_{2}$. Entryl, $\mathrm{H}_{3} \mathrm{BO}_{3}$ to L-lysine molar ratio=6.89:1; Entry $2, \mathrm{H}_{2} \mathrm{SO}_{4}$ to L-lysine molar ratio=1.13:1; Entry 3, $\mathrm{H}_{2} \mathrm{SO}_{4}$ to L-lysine molar ratio $=3.75: 1$

\begin{tabular}{cccccccccc}
\hline Entry & conversion & \multicolumn{8}{c}{ Yield (\%) } \\
\cline { 3 - 10 } & $(\%)$ & PD & 2-MPD & 3-MPD & CA & 1,5-DAP & 2-PDM & 3-PDM & L \\
\hline 1 & 100 & 16.88 & 0.10 & 0.55 & 0.00 & 0.00 & 0.00 & 0.00 & 0.00 \\
2 & 97 & 42.83 & 8.93 & 0.83 & 28.75 & 0.00 & 1.28 & 1.91 & 0.00 \\
3 & 21 & 0.00 & 0.00 & 0.00 & 0.74 & 1.12 & 0.56 & 0.73 & 7.37 \\
\hline
\end{tabular}

Denotation: PD(piperidine), 2-MPD(2-methylpiperidine), 3-MPD(3-methylpiperidine), $\mathrm{CA}$ (cadaverine), 1,5-DAP(1,5-diaminopentane), 2-PDM(2-piperidinemethanol), 3-PDM(3-piperidinemethanol), L(lysinol)

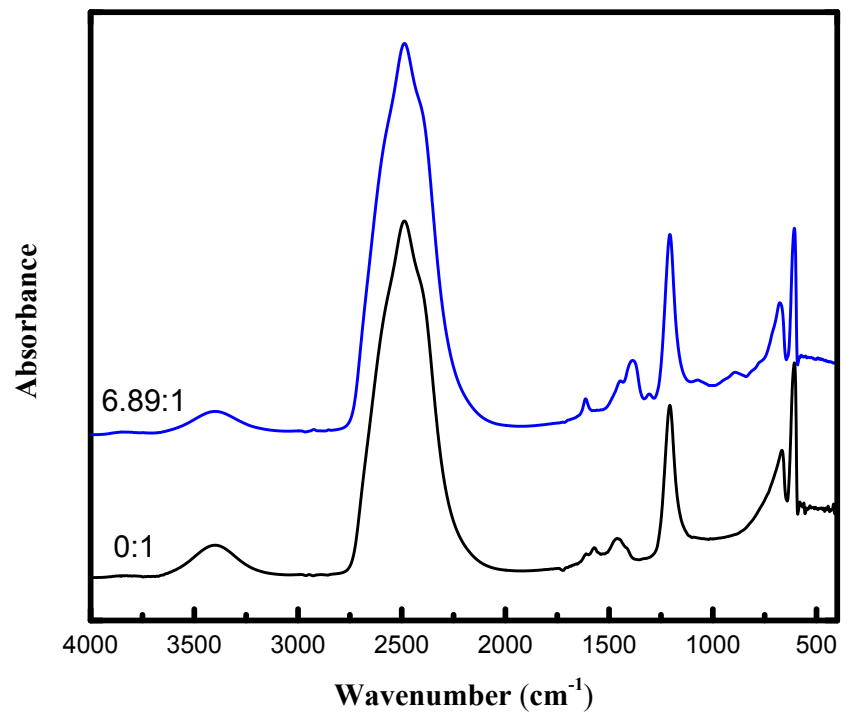

Figure S8. Effect of $\mathrm{H}_{3} \mathrm{BO}_{3}$ to L-lysine molar ratio on the FTIR spectra of L-lysine in $\mathrm{D}_{2} \mathrm{O}$ at room temperature. 


\section{Determination of the reaction pathways}

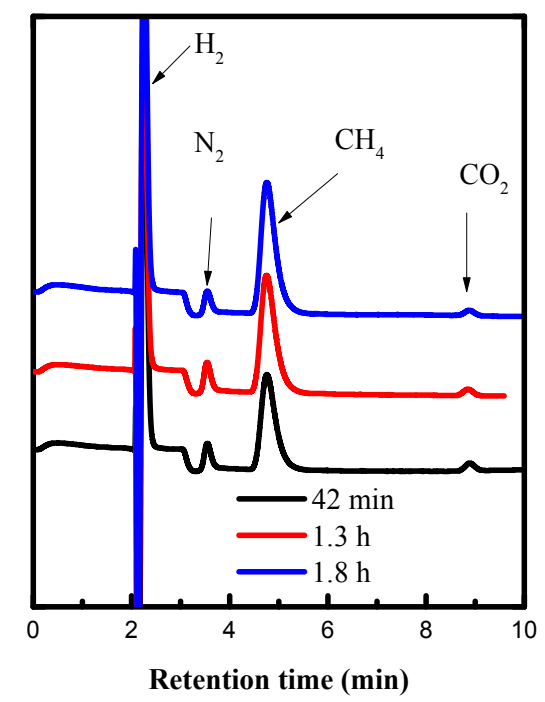

(a)

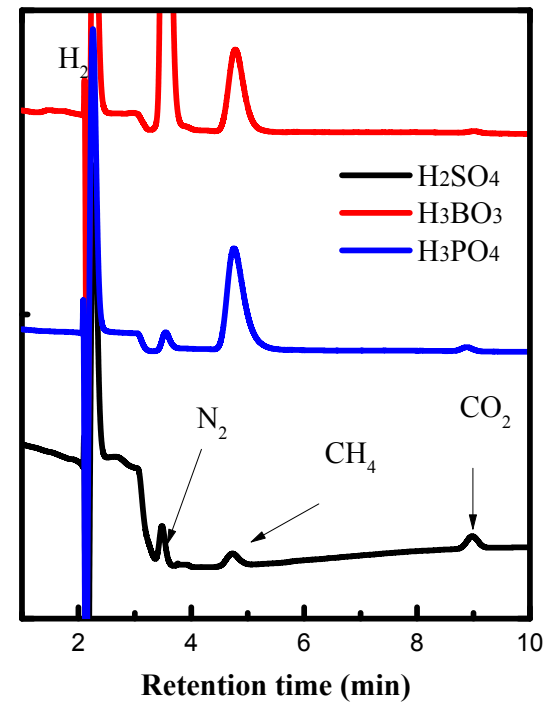

(b)

Figure S9 GC-TCD analysis of the gaseous phase, (a) after different reaction times, reaction condition: Lysine $(0.5 \mathrm{mmol}), 5 \% \mathrm{Ru} / \mathrm{C}(0.03 \mathrm{~g})$, water $(5 \mathrm{~mL}), \mathrm{H}_{3} \mathrm{PO}_{4}(3$ mmol), $200{ }^{\circ} \mathrm{C}, 28.2$ bar $\mathrm{H}_{2}$; (b) with different acids, 1) $\mathrm{H}_{3} \mathrm{PO}_{4}$, reaction condition: Lysine $(0.5 \mathrm{mmol}), 5 \% \mathrm{Ru} / \mathrm{C}(0.03 \mathrm{~g})$, water $(5 \mathrm{~mL}), \mathrm{H}_{3} \mathrm{PO}_{4}(3 \mathrm{mmol}), 200{ }^{\circ} \mathrm{C}, 1.8 \mathrm{~h}, 28.2 \mathrm{bar}$ $\left.\mathrm{H}_{2} ; 2\right) \mathrm{H}_{3} \mathrm{BO}_{3}$, reaction condition: Lysine $(0.5 \mathrm{mmol}), 5 \% \mathrm{Ru} / \mathrm{C}(0.03 \mathrm{~g})$, water $(5 \mathrm{~mL})$, $\mathrm{H}_{3} \mathrm{BO}_{3}(0.2 \mathrm{~g}), 200{ }^{\circ} \mathrm{C}, 1 \mathrm{~h}, 28.2$ bar $\left.\mathrm{H}_{2} ; 3\right) \mathrm{H}_{2} \mathrm{SO}_{4}$, reaction condition: Lysine (0.5 mmol), $5 \% \mathrm{Ru} / \mathrm{C}(0.03 \mathrm{~g})$, water $(5 \mathrm{~mL}), \mathrm{H}_{2} \mathrm{SO}_{4}(1.88 \mathrm{mmol}), 200{ }^{\circ} \mathrm{C}, 1 \mathrm{~h}, 28.2 \mathrm{bar} \mathrm{H}_{2}$. A trace amount of nitrogen was still present after purging with $\mathrm{H}_{2}$. 


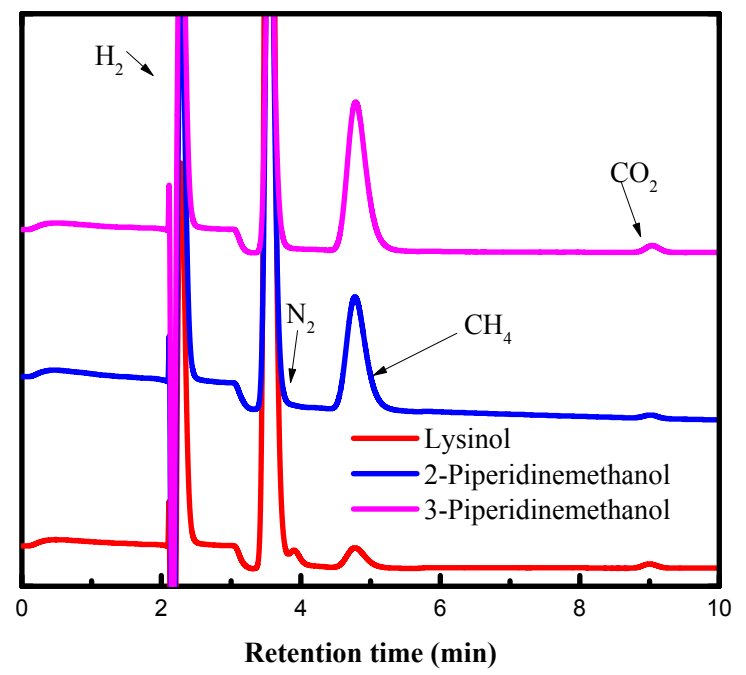

Figure S10 GC-TCD analysis of the gaseous phase after the conversion of three possible intermediates (2-piperidinemethanol, 3-piperidinemethanol, lysinol). 


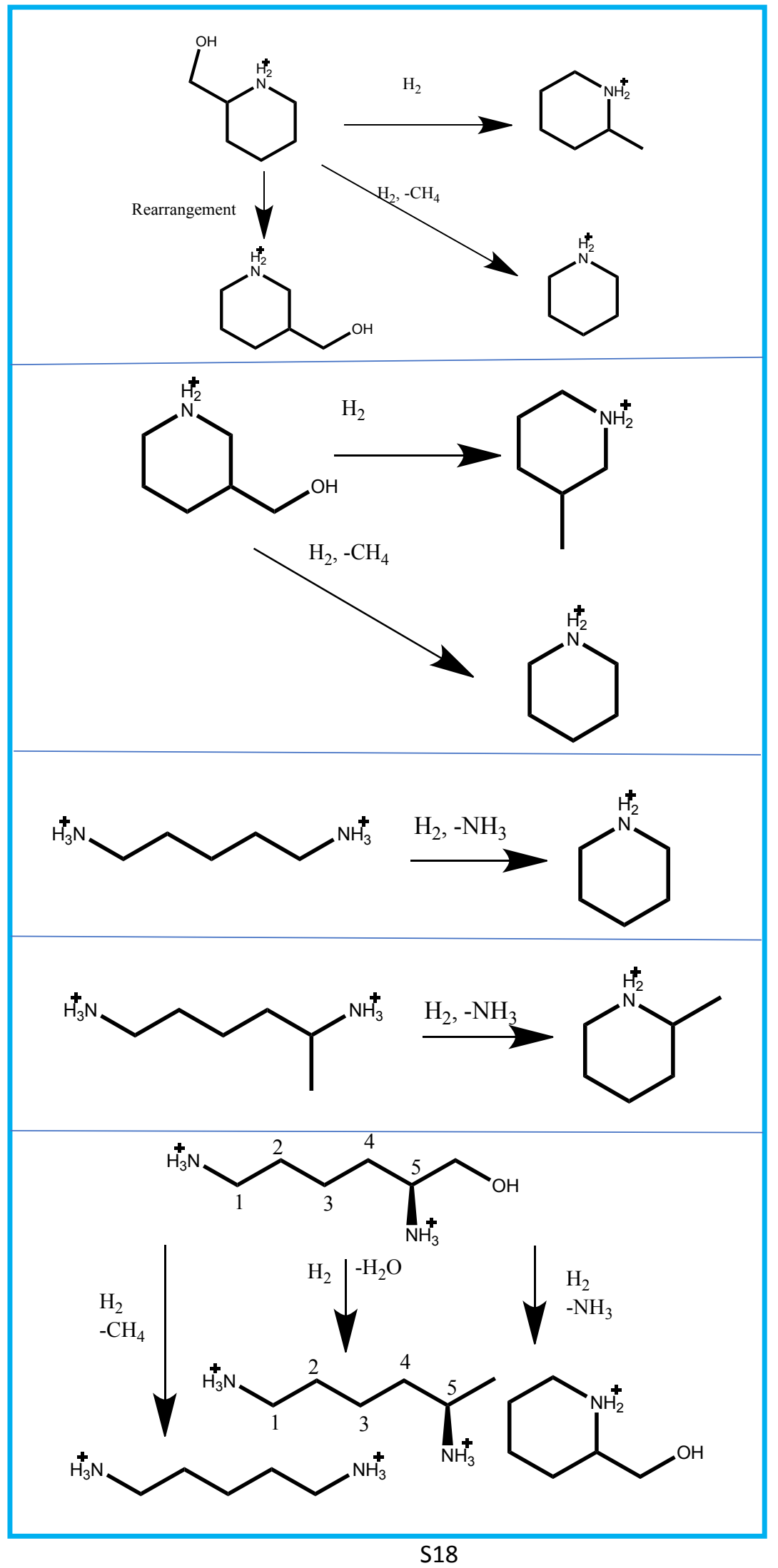


Scheme S1 Probe reaction pathways: 1) From 2-piperidinemethanol to 2-methylpiperidine, 3-piperidinemethanol, methane, and piperidine; 2) From 3-piperidinemethanol to 3-methylpiperidine, methane, and piperidine; 3) From cadaverine to piperidine and ammonia; 4) From 1,5-diaminohexane to 2-methylpiperidine and ammonia; 5) From lysinol to 2-piperidinemethanol, cadaverine, methane, ammonia, and 1,5-diaminohexane.

\section{Powder X-ray diffraction (XRD)}

The powder X-ray diffraction (XRD) patterns of the fresh $\mathrm{Ru} / \mathrm{C}$ and used $\mathrm{Ru} / \mathrm{C}$ catalysts were collected on a Rigaku Miniflex 600 XRD powder x-ray diffractometer parameters $(40 \mathrm{kV}, 15 \mathrm{~mA})$ with the following test parameters: scanning between $10^{\circ}$ and $90^{\circ}(2 \theta)$ with $0.01^{\circ}$ steps and a scanning speed of $5^{\circ} \mathrm{min}^{-1}$.

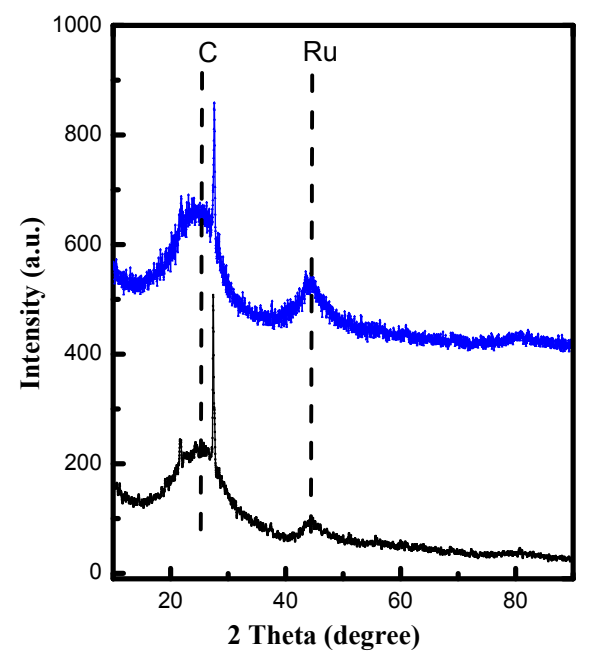

Figure S11. XRD patterns of fresh $\mathrm{Ru} / \mathrm{C}$ and used $\mathrm{Ru} / \mathrm{C}$. 
The XRD patterns of fresh $\mathrm{Ru} / \mathrm{C}$ and used $\mathrm{Ru} / \mathrm{C}$ are depicted in Figure S11. All the peaks detected showed great agreement with the literature ${ }^{6,7}$, which confirmed that the used $\mathrm{Ru} / \mathrm{C}$ showed the same phases as the fresh $\mathrm{Ru} / \mathrm{C}$.

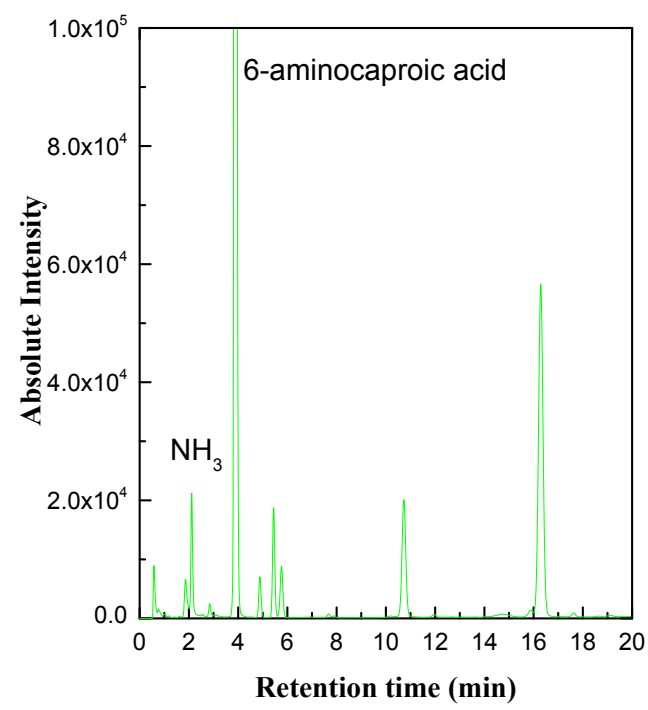

Figure S12 HPLC spectrum (UV-Vis detector) of the products from the conversion of 6-aminocaproic acid. Reaction condition: 6-aminocaproic acid $(0.5 \mathrm{mmol}), 5 \% \mathrm{Ru} / \mathrm{C}$

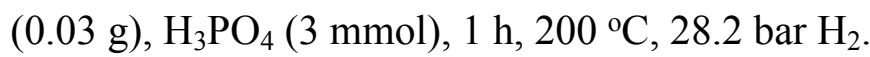

\section{Reference:}

(1) Felpin, F. X.; Fouquet, E. A Useful, Reliable and Safer Protocol for Hydrogenation and the Hydrogenolysis of o-Benzyl Groups: The in Situ Preparation of an Active Pd 0/C Catalyst with Well-Defined Properties. Chem. - A Eur. J. 2010, 16 (41), 12440-12445. https://doi.org/10.1002/chem.201001377.

(2) Kim, Y. H.; Kim, H. J.; Shin, J. H.; Bhatia, S. K.; Seo, H. M.; Kim, Y. G.; Lee, Y. 
K.; Yang, Y. H.; Park, K. Application of Diethyl Ethoxymethylenemalonate (DEEMM) Derivatization for Monitoring of Lysine Decarboxylase Activity. $J$. Mol. Catal. B Enzym. 2015, 115, 151-154. https://doi.org/10.1016/j.molcatb.2015.01.018.

(3) Rebane, R.; Herodes, K. A Sensitive Method for Free Amino Acids Analysis by Liquid Chromatography with Ultraviolet and Mass Spectrometric Detection Using Precolumn Derivatization with Diethyl Ethoxymethylenemalonate: Application to the Honey Analysis. Anal. Chim. Acta 2010, 672 (1-2), 79-84. https://doi.org/10.1016/j.aca.2010.04.014.

(4) Metkar, P. S.; Scialdone, M. A.; Moloy, K. G. Lysinol: A Renewably Resourced Alternative to Petrochemical Polyamines and Aminoalcohols. Green Chem. 2014, 16 (10), 4575-4586. https://doi.org/10.1039/c4gc01167h.

(5) Wentrcek, P. W.; McCarty, J. G.; Ablow, C. M.; Wise, H. Deactivation of Alumina-Supported Nickel and Ruthenium Catalysts by Sulfur Compounds. $J$. Catal. 1980, 61 (1), 232-241. https://doi.org/10.1016/0021-9517(80)90359-0.

(6) Giorgi, L.; Pozio, A.; Bracchini, C.; Giorgi, R.; Turtù, S. H2 and H2/CO Oxidation Mechanism on $\mathrm{Pt} / \mathrm{C}, \mathrm{Ru} / \mathrm{C}$ and $\mathrm{Pt}-\mathrm{Ru} / \mathrm{C}$ Electrocatalysts. J. Appl. Electrochem. 2001, 31 (3), 325-334. https://doi.org/10.1023/A:1017595920726.

(7) Miyazawa, T.; Koso, S.; Kunimori, K.; Tomishige, K. Development of a Ru/C 
Catalyst for Glycerol Hydrogenolysis in Combination with an Ion-Exchange

Resin. Appl. Catal. A Gen. 2007, 318, 244-251. https://doi.org/10.1016/j.apcata.2006.11.006. 